\title{
Spheroidal weathering of basalt from Gebel Qatrani, Fayum Depression, Egypt
}

\author{
Essam El-Hinnawi*, S. D. Abayazeed and A. S. Khalil
}

\begin{abstract}
Background: Three stages of basalt weathering are known: early or incipient weathering, intermediate weathering and advanced weathering. The Late Oligocene basalt of Gebel Qatrani in Fayum Depression, Egypt, shows signs of early weathering, particularly exhibited in basalt spheroids found at the top of the basalt flow. The present paper gives the results of detailed petrographical, mineralogical and geochemical study of the weathering of these basalt spheroids.

Results: The core-stones of the basalt spheroids are composed of phenocrystals of plagioclase feldspars and clinopyroxenes set in a groundmass of tiny feldspars and pyroxenes, relatively altered olivine and opaque minerals. The basalt is subalkali (tholeiitic). The outer weathered shells surrounding the core-stones are composed of partly altered feldspars and pyroxenes. The calculated weathering indices show that there is marked weathering trend from the core-stones of the spheroids to the outer shells. The chemical mobility of the elements shows marked depletion of $\mathrm{Mg}, \mathrm{Ca}, \mathrm{Na}$ and $\mathrm{K}$ from the core-stones to the outer shells due to the weathering of olivine, pyroxene and feldspars. The trace elements $\mathrm{Rb}, \mathrm{Sr}, \mathrm{Ni}, \mathrm{V}, \mathrm{Cr}$ and $\mathrm{Zn}$ are also depleted.

Conclusions: The weathering of basalt spheroids from Gebel Qatrani, Fayum Depression, Egypt, is of the incipient type. The degree of weathering from the core-stones of the basalt spheroids to the corresponding weathered shells indicates that the weathering occurred under predominantly semiarid to arid conditions.
\end{abstract}

Keywords: Basalt spheroids, Gebel Qatrani, Fayum depression, Weathering indices, Element mobility

\section{Introduction}

The Fayum Depression has an area of about 12,000 $\mathrm{km}^{2}$ and lies about $100 \mathrm{~km}$ south-west of Cairo (Fig. 1). The geology of the area was studied in detail by Beadnell (1905), and his work has remained the basis for subsequent studies (Said 1962; Vondra 1974; Bown and Vondra 1974 1974; Bown and Kraus 1988; Gingerich 1992, 1993, among others). These studies indicate that the sedimentary successions encountered in Fayum Depression are of middle and late Eocene and Oligocene age and can be divided into the following, formations, from base to top (Fig. 1):
1 Wadi Rayan Formation This formation is of middle Eocene age and forms the base of the Fayum Depression and is exposed in its southern part, reaching a thickness of about $130 \mathrm{~m}$. It is mainly composed of limestone, with Nummulites gizehensis, argillaceous sand and sandy shale (Beadnell 1905; Said 1962). The formation was deposited on an open marine continental shelf. Abd-Elshafy et al. (2007) analyzed the faunal community of the formation at three locations in Wadi Rayan and concluded that the faunal content, as well as the lithology, indicates the alternation between two transgressive sedimentary cycles enclosing a regressive phase.

2 Gehannam Formation Also known as ravine beds, this formation, which is of middle Eocene age, conformably overlies the Wadi Rayan Formation and attains a thickness of about $70 \mathrm{~m}$. It is mainly com- 


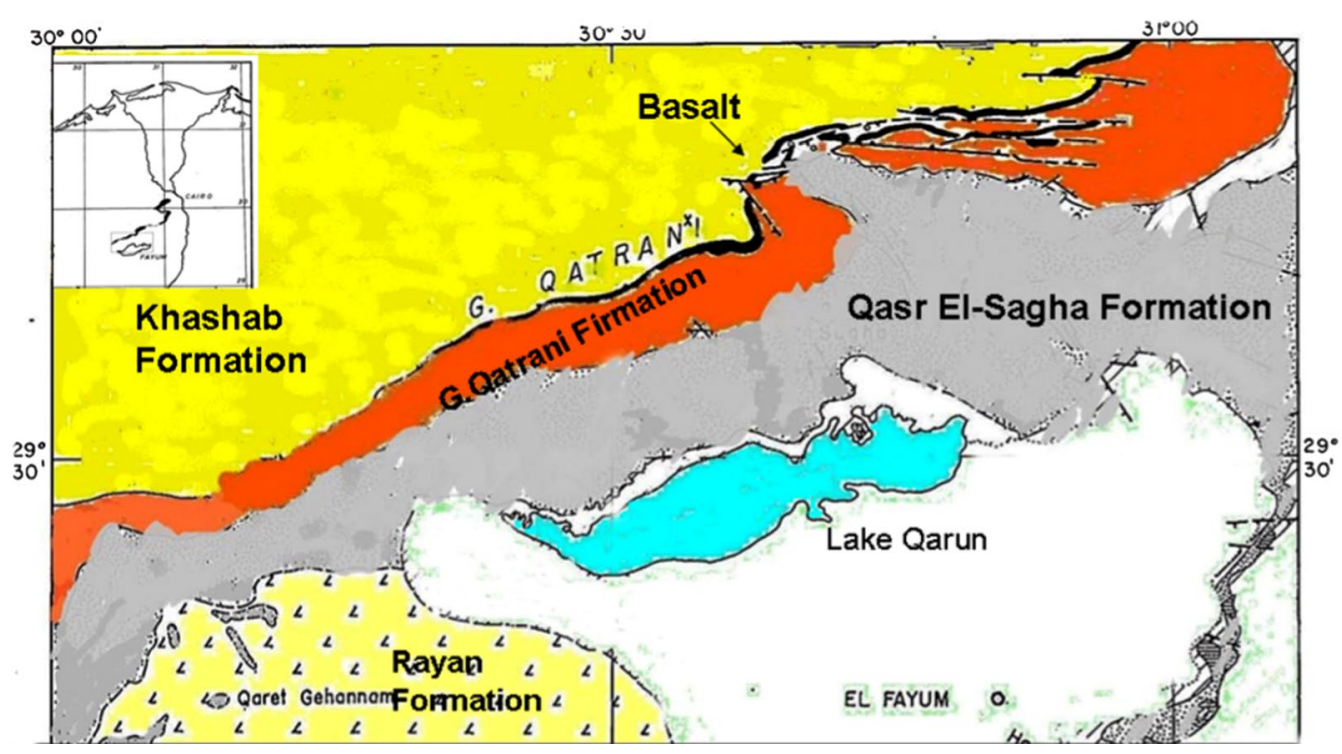

\begin{tabular}{|c|c|c|c|}
\hline \multicolumn{2}{|l|}{ Age } & Formation & Thickness \\
\hline \multicolumn{2}{|l|}{ Miocene } & Khashab Formation & $>100 \mathrm{~m}$ \\
\hline \multirow[t]{2}{*}{ Oligocene } & \multirow{2}{*}{ Late } & Basalt & $20 \mathrm{~m}$ \\
\hline & & $\begin{array}{l}\text { Gebel Qatrani } \\
\text { mation }\end{array}$ & $340 \mathrm{~m}$ \\
\hline \multirow{4}{*}{ Eocene } & \multirow[t]{2}{*}{ Late } & $\begin{array}{l}\text { Qasr El-Sagha } \\
\text { Formation }\end{array}$ & $200 \mathrm{~m}$ \\
\hline & & $\begin{array}{l}\text { Birquet Qarun } \\
\text { Formation }\end{array}$ & $60 \mathrm{~m}$ \\
\hline & \multirow[t]{2}{*}{ Middle } & Gehannam Formtrion & $70 \mathrm{~m}$ \\
\hline & & Wadi Rayan Formation & $130 \mathrm{~m}$ \\
\hline
\end{tabular}

Fig. 1 Geological map of Fayum Depression (simplified after Said 1962 and CONOCO Geological map of Egypt)

posed of gypsiferous shale, marl, limestone and sands and was deposited on a shallow, but open marine shelf (Gimgerich 1992).

3 Birket Qarun Formation This formation is of late Eocene age and conformably overlies the Gehannam Formation. It has a thickness of about $50 \mathrm{~m}$ and is composed of sandstones and shale, with a few bands of limestone. Lithologically the Birquet Qarun Formation is indistinguishable from the underlying one, but is paleontologically distinct, as it carries different fossil species (Beadnell 1905). The Birket Qarun Formation was a submerged barrier bar, rather than a beach complex (Bown and Kraus 1988; Gingerich 1992).

4. Qasr El-Sagha Formation This formation is also of late Eocene age and conformably overlies the Birket
Qarun Formation. It varies in thickness from one location to another in Fayum Depression and is generally in the range of 175-200 m. Four distinct facies have been recognized in Qasr El-Sagha Formation: (a) interbedded claystone, siltstone and quartz sandstone facies; (b) quartz sandstone facies; (c) arenaceous bioclasic carbonate facies; and (d) gypsiferous and carbonaceous laminated claystone and siltstone facies (Vondra 1974). (Facies (a) and (b) have been called the Dir Abu Lifa Member, and overlies facies (c) and (d) which have been called the Temple Member (Bown and Kraus 1988). Both the Dir Abu Lifa and the Temple Members represent the upper part of Qasr El-Sagha Formation. At locations south and west of Qasr El-Sagha, Gingerich (1992) introduced two additional members: the Harab Member which 
forms the middle part of Qasr El-Sagha Formation, and the Um Rigl Member which forms the lower part of the Formation. The Harab Member is composed of brown shale, whereas the Umm Rigl Member is of similar facies as the Temple Member but is separated from it by Harab Member. The Umm Rigl Member was deposited in a shallow outer lagoonal environment; the Harab Member in a deeper central lagoonal environment; the Temple Member in a shallow inner lagoonal environment; and the Dir Abu Lifa Member in a non-lagoonal (deltaic or interdeltaic) environment (Vondra 1974; Bown and Kraus 1988; Gingerich 1992).

5 Jebel Qatrani Formation This formation is of Oligocene age and is separated from the underlying Qasr El-Sagha Formation by an unconformity that involved erosion of up to $70 \mathrm{~m}$ of Qasr El-Sagha strata in places before the deposition of Gebel Qatrani Formation (Gingerich 1992). The lithology of Gebel Qatrani Formation is rather complex and is composed of about $340 \mathrm{~m}$ of variegated alluvial rocks: fine to coarse sandstone, granule and pebble conglomerate, sandy mudstone, carbonaceous mudstone and limestone. The lower part of Gebel Qatrani Formation is assumed to have been deposited by meandering streams, whereas the upper part of the formation was deposited under the influence of an encroaching marine strandline (Bown and Vondra 1974, 1974; Bown and Kraus 1988).

In later Oligocene times, a tensional tectonic episode occurred and was accompanied by northwest-trending normal faults throughout the northern parts of the Eastern and Western Deserts of Egypt. Basaltic lavas were extruded from these fissures at different locations (Rittmann 1954). In the northern part of Fayum Depression, these basaltic lavas capped the uppcr Qatrani escarpment varying in thickness from 2 to $25 \mathrm{~m}$. (The latter thickness has been recorded at Widan El Faras.) In outcrops where the basalt is thinnest, it appears that it was a single flow; however, some authors believe that there were two or more flows (Fleagle et al. 1986; Bown and Kraus 1988). The flows overlie the Gebel Qatrani Formation with a pronounced erosional unconformity. Meneisy and Abdel Aal (1984) determined the whole rock K/ Ar ages of two samples of these basalts as $23.8 \pm 0.7 \mathrm{Ma}$ and 24.4 $\pm 9.7 \mathrm{Ma}$, and Bown and Kraus (1988) reported two ages: $24.7 \pm 0.4 \mathrm{Ma}$ and $27.0 \pm 3 \mathrm{Ma}$. Meneisy (1990) compiled other K/Ar age data of $27 \pm 1 \mathrm{Ma}, 25 \pm 1 \mathrm{Ma}$ and $23 \pm$ Ma. However, Bown and Kraus (1988) indicated that a sample of basalt taken from the lowest part of the flow near the top of Gebel Qatrani Formation gave an age of $31 \pm 1 \mathrm{Ma}$ and, therefore, stated that the basalt might be of late Early Oligocene to Late Oligocene. However, on average the previously mentioned data show that the age of Gebel Qatrani basalt is $25.7 \mathrm{Ma}$, i.e., of Late Oligocene age, according to the International Chronostratigraphic Chart (Cohen et al. 2013; updated 2017).

The petrography and geochemistry of Gebel Qatrani basalt are described in several studies (El-Hinnawi 1965; El-Hinnawi and Abdel Maksoud 1968, 1972; Heikal et al. 1983; Sharara 1984; Abdel Meguid et al. 1992; Endress et al 2011). The basalt has generally an ophitic texture, with plagioclase feldspars clinopyroxene phenocrysts set in a fine groundmass of plagioclase, clinopyroxene, occasional olivine (mostly altered), opaque minerals and altered glass.

The basalt of Gebel Qatrani is unconformably overlain by Miocene alluvial sediments (the Khashab Formation). The contact between the basalt and the Khashab Formation is markedly erosional, and scours in the top of the basalt are filled with coarse sand, sandstones containing basalt debris and other pebble conglomerate (Said 1962; Bown and Kraus 1988). The basalt itself is not markedly weathered; no weathering profiles have been detected and the weathering observed is predominantly rind weathering. At the top of the basalt flows of Gebel Qatrani, spheroids of basalt are occasionally encountered.

The present paper describes the mineralogy and geochemistry of the cores and weathered rims of these basalt spheroids and discusses the paleo-environmental conditions of their weathering.

\section{Samples and methods}

The term "spheroidal weathering" is used if concentric shells completely surround the core-stone (Ollier 1971). A difference exists between spheroidal weathering and exfoliation. In spheroidal weathering, the weathering process acts all around the spheroid, weathering the underside as well as the top. Patino et al. (2003) pointed out that basalt flows have cooling features that serve as hydrologic discontinuities which function as major pathways for fluids that are the agents of weathering. In incipient and intermediate weathering stages, the concentric shells surrounding the basalt spheroids still contain part of the primary minerals and/or secondary derivatives. In advanced stages of weathering, however, the shells are completely transformed into argillaceous material.

In Gebel Qatrani the basalt spheroids (Fig. 2) encountered vary in size and have gray to gray-greenish color. In the present work, several samples were collected, taking care that their outer weathered shells are more or less complete surrounding the core-stones. The collected samples were generally egg-shaped, the longest dimension of which varied from 8 to $15 \mathrm{~cm}$, the intermediate dimension from 6 to $12 \mathrm{~cm}$, and shortest dimension 


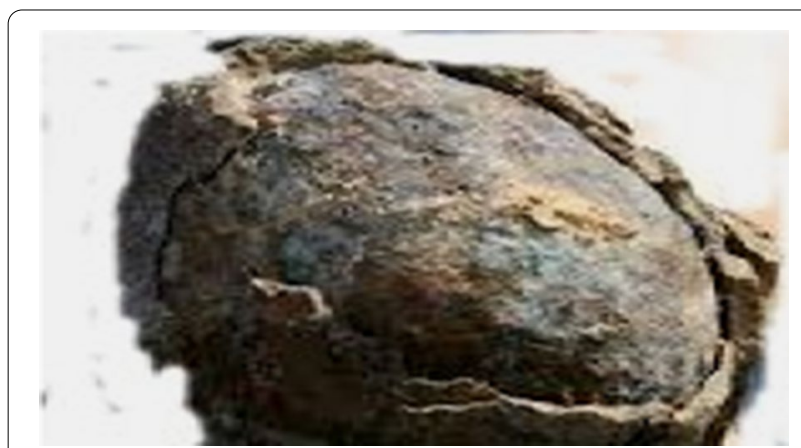

Fig. 2 Photograph of basalt spheroid showing core-stone and outer weathered shell

from 6 to $10 \mathrm{~cm}$. The weathered shells varied in thickness between 2 and $5 \mathrm{~mm}$.

In laboratory, the outer weathered shells were carefully detached from the core-stones. Thin sections of the latter were prepared for petrographic study. The shell material was powdered for analysis by X-ray diffraction. (The analyses were carried out at the Metallurgical Institute, Tebbin, Cairo, using a Philips X-ray diffractometer; scanning was carried out at $2 \varnothing$ of $1^{\circ}$ per minute between $4^{\circ}$ and $60^{\circ}$.) The major and trace element composition of both the powdered core-stones and the shells were determined by X-ray fluorescence (XRF), at the Central Laboratories of the Egyptian Geological Survey, Dokki, Cairo.

\section{Results}

\section{Petrography and mineralogy of the basalt spheroids}

The examination of thin sections of the core-stones of the basalt spheroids under the polarizing microscope revealed that they exhibit an ophitic texture, with plagioclase feldspar and clinopyroxene phenocrysts within a fine groundmass of plagioclase, clinopyroxene, opaque minerals, glassy and altered minerals. The modal composition of the core-stones was determined by point counting. It consists of an average of $56 \%$ plagioclase feldspars, $27 \%$ clinopyroxene, $6 \%$ opaque minerals and $11 \%$ glass and alteration products.

The plagioclase phenocrysts occur as tabular subhedral to euhedral crystals with an average size of $1 \times 0.35 \mathrm{~mm}$. The crystals exhibit albite and albite-carlsbad twinning, often with oscillatory zoning. Some of the crystals show tiny inclusions of pyroxene. The composition of the plagioclase varies from one crystal to another (El-Hinnawi and Abdel Maksoud 1968; Endress et al. 2011). On the average, it is composed of $\mathrm{An}_{68} \mathrm{Ab}_{30} \mathrm{Or}_{2}$. In contrast to the plagioclase phenocrysts, the plagioclase in the groundmass is present as tiny laths, about $0.5 \times 0.1 \mathrm{~mm}$, mingled with clinopyroxene, opaque and altered grains.
Clinopyroxene is present as anhedral to subhedral tabular phenocrysts about $1.7 \times 1.3 \mathrm{~mm}$. The crystals exhibit lamellar twining, some are zoned. The composition of the clinopyroxene was determined optically and found to range from pigeonite to augite. This is in agreement with the findings of Endress et al. (2011). Some clinopyroxene crystals contain tiny inclusions of plagioclase, and some are corroded at the edges. The clinopyroxene in the groundmass is in the form of tiny grains intermixed with plagioclase, opaque and altered material. Few samples show the presence of altered olivine (iddingsite) in the groundmass.

$\mathrm{X}$-ray powder diffraction analysis of the weathered shells separated from the basalt spheroids showed the presence of sharp peaks of plagioclase feldspars as the predominant minerals present. In one sample (sample No. 1) peaks of pyroxene have been detected. This indicates that the weathering of the core-stones of the basalt spheroids was at an initial (incipient) stage; the main minerals (the plagioclase and the ferromagnesian minerals) were not completely altered as in advanced weathering stages. No marked peaks of clay minerals were detected in the studied samples, although Morsy and Attia (1983) reported the presence of montmorillonitevermiculite, chlorite and illite in two samples.

\section{Geochemistry of the basalt spheroids}

Table 1 gives the chemical analyses of core-stones and shells of seven representative basalt spheroids, and Table 2 gives the distribution of some trace elements in the studied samples. Figure 3 shows the relationship between the total alkali $\left(\mathrm{Na}_{2} \mathrm{O}+\mathrm{K}_{2} \mathrm{O}\right)$ and silica for these samples and indicates that all samples fall below the Macdonald and Katsura boundary line (1964) in the subalkali (i.e., tholeiitic) field. The figure indicates that shells have lower content of alkalis which illustrates the loss of these elements due to weathering. On the other hand, there is a slight increase in the silica content indicating the conservative behavior of silica during incipient weathering.

To assess the extent of weathering, several weathering indices have been proposed, e.g., the weathering index of Parker (WIP, Parker 1970), the chemical index of alteration (CIA, Nesbitt and Young 1982), the chemical index of weathering (CIW, Harnois 1988) and more recently, the mafic index of alteration under oxiding and reducing conditions (MIA(O), MIA(R)) which includes Fe and Mgoxides (Babechuk et al. 2014). Each uses the molecular proportions of major element oxides, with variations on which oxides are included, and assumptions about element mobility. In the present work, the following indices have been calculated and used to describe the changes that accompanied the spheroidal weathering of Gebel Qatrani basalt: 
Table 1 Chemical analyses and weathering indices

\begin{tabular}{|c|c|c|c|c|c|c|c|c|}
\hline & 1 & 2 & 3 & 4 & 5 & 6 & 7 & $A v$ \\
\hline \multicolumn{9}{|c|}{ Core-stone } \\
\hline $\mathrm{SiO}_{2}$ & 49.66 & 49.28 & 49.76 & 49.75 & 49.96 & 48.75 & 49.08 & 49.46 \\
\hline $\mathrm{TiO}_{2}$ & 2.19 & 2.08 & 2.12 & 2.12 & 2.1 & 2.33 & 2.89 & 2.26 \\
\hline $\mathrm{Al}_{2} \mathrm{O}_{3}$ & 13.67 & 14.63 & 14.41 & 14.42 & 14.7 & 12.9 & 15.15 & 14.27 \\
\hline $\mathrm{Fe}_{2} \mathrm{O}_{3}^{\top}$ & 14.98 & 13.91 & 13.82 & 13.88 & 13.58 & 13.62 & 13.58 & 13.91 \\
\hline $\mathrm{MnO}$ & 0.13 & 0.15 & 0.15 & 0.15 & 0.15 & 0.16 & 0.15 & 0.15 \\
\hline $\mathrm{MgO}$ & 6.68 & 6.92 & 6.95 & 6.96 & 6.62 & 6.19 & 6.33 & 6.66 \\
\hline $\mathrm{CaO}$ & 9.72 & 9.41 & 9.94 & 9.84 & 10.03 & 9.84 & 9.76 & 9.79 \\
\hline $\mathrm{Na}_{2} \mathrm{O}$ & 2.39 & 2.13 & 2.19 & 2.17 & 2.21 & 2.34 & 2.58 & 2.29 \\
\hline $\mathrm{K}_{2} \mathrm{O}$ & 0.78 & 0.73 & 0.81 & 0.8 & 0.79 & 0.79 & 0.78 & 0.78 \\
\hline $\mathrm{P}_{2} \mathrm{O}_{5}$ & 0.26 & 0.21 & 0.21 & 0.21 & 0.22 & 0.24 & 0.3 & 0.24 \\
\hline LOI & 0.50 & 0.61 & 0.31 & 0.25 & 0.21 & 0.85 & 0.66 & 0.48 \\
\hline Total & 100.97 & 100.07 & 100.66 & 100.54 & 100.56 & 99.92 & 100.24 & 100.42 \\
\hline \multicolumn{9}{|c|}{ Weathering indices* } \\
\hline WIP & 71.5 & 69.3 & 71.3 & 70.1 & 70.6 & 72.9 & 72.4 & 71.16 \\
\hline $\mathrm{ClA}$ & 38.4 & 41.2 & 39.3 & 39.8 & 39.8 & 36.9 & 40.4 & 39.40 \\
\hline CIW & 38.7 & 41.3 & 39.9 & 40.2 & 40.2 & 37.2 & 40.8 & 39.76 \\
\hline $\mathrm{MIA}(\mathrm{O})$ & 37.4 & 38.0 & 37.0 & 37.1 & 37.5 & 36.0 & 38.3 & 37.33 \\
\hline \multicolumn{9}{|c|}{ Shell around core-stone } \\
\hline $\mathrm{SiO}_{2}$ & 50.68 & 52.21 & 52.68 & 48.73 & 48.90 & 50.70 & 50.11 & 50.57 \\
\hline $\mathrm{TiO}_{2}$ & 2.00 & 2.00 & 2.10 & 2.20 & 2.00 & 2.20 & 2.80 & 2.19 \\
\hline $\mathrm{Al}_{2} \mathrm{O}_{3}$ & 14.70 & 16.32 & 16.57 & 16.44 & 16.70 & 15.90 & 17.15 & 16.25 \\
\hline $\mathrm{Fe}_{2} \mathrm{O}_{3}^{\top}$ & 15.00 & 12.08 & 12.18 & 14.88 & 14.50 & 14.62 & 15.58 & 14.12 \\
\hline $\mathrm{MnO}$ & 0.14 & 0.15 & 0.15 & 0.14 & 0.13 & 0.13 & 0.13 & 0.14 \\
\hline $\mathrm{MgO}$ & 5.80 & 4.20 & 4.29 & 5.96 & 4.62 & 4.19 & 4.38 & 4.78 \\
\hline $\mathrm{CaO}$ & 8.10 & 8.00 & 7.16 & 7.80 & 8.03 & 7.81 & 7.50 & 7.77 \\
\hline $\mathrm{Na}_{2} \mathrm{O}$ & 2.00 & 2.00 & 2.00 & 2.01 & 2.00 & 1.90 & 1.99 & 1.99 \\
\hline $\mathrm{K}_{2} \mathrm{O}$ & 0.72 & 0.70 & 0.65 & 0.65 & 0.70 & 0.70 & 0.72 & 0.69 \\
\hline $\mathrm{P}_{2} \mathrm{O}_{5}$ & 0.24 & 0.41 & 0.30 & 0.22 & 0.20 & 0.23 & 0.25 & 0.26 \\
\hline LOI & 0.80 & 1.20 & 1.50 & 1.20 & 1.90 & 1.50 & 0.38 & 1.21 \\
\hline Total & 100.16 & 99.27 & 99.76 & 100.73 & 100.72 & 99.87 & 100.99 & 100.21 \\
\hline \multicolumn{9}{|c|}{ Weathering indices ${ }^{a}$} \\
\hline WIP & 62.7 & 58.0 & 50.9 & 61.0 & 59.2 & 55.8 & 55.3 & 57.56 \\
\hline $\mathrm{ClA}$ & 44.7 & 48.1 & 50.4 & 48.2 & 47.8 & 47.6 & 50.1 & 48.13 \\
\hline CIW & 44.9 & 47.8 & 50.4 & 48.5 & 48.3 & 47.9 & 50.9 & 48.39 \\
\hline $\operatorname{MIA}(\mathrm{O})$ & 41.2 & 46.0 & 47.3 & 44.2 & 46.4 & 47.3 & 49.0 & 45.91 \\
\hline
\end{tabular}

a See text

WIP $=\left[\left(2 \mathrm{Na}_{2} \mathrm{O} / 0.35\right)+(\mathrm{MgO} / 0.9)+\left(2 \mathrm{~K}_{2} \mathrm{O} / 0.25\right)+\right.$ $(\mathrm{CaO} / 0.7)] \times 100$ (Parker 1970).

$\mathrm{CIA}=\left[\mathrm{Al}_{2} \mathrm{O}_{3} /\left(\mathrm{Al}_{2} \mathrm{O}_{3}+\mathrm{CaO} *+\mathrm{Na}_{2} \mathrm{O}+\mathrm{K}_{2} \mathrm{O}\right)\right] \times 100$

(Nesbitt and Young 1982).

$\mathrm{CIW}=\left[\mathrm{Al}_{2} \mathrm{O}_{3} /\left(\mathrm{Al}_{2} \mathrm{O}_{3}+\mathrm{CaO} *+\mathrm{Na}_{2} \mathrm{O}\right)\right] \times 100$

(Harnois 1988).

$\mathrm{MIA}(\mathrm{O})=\left(\left(\mathrm{Al}_{2} \mathrm{O}_{3}+\mathrm{Fe}_{2} \mathrm{O}_{3} \mathrm{~T}\right) /\left(\mathrm{Al}_{2} \mathrm{O}_{3}+\mathrm{Fe}_{2} \mathrm{O}_{3 \mathrm{~T}}+\mathrm{MgO}\right.\right.$

$\left.\left.+\mathrm{CaO}+\mathrm{Na}_{2} \mathrm{O}+\mathrm{K}_{2} \mathrm{O}\right)\right) \times 100$ (Babechuck et al. 2014).
The weathering index of Parker (WIP) is considered relatively sensitive to the chemical variations in the early stages of weathering because it allows for differential mobility of cations based on their bond strength with oxygen. WIP values range between 100 and 0 , with smaller numbers indicating enhanced weathering. In all the studied samples (Table 1), there is a decrease of WIP from the core-stones to the corresponding shells, with varying degrees. Sample No. 3 shows the highest difference in WIP from the core-stone to the weathered 
Table 2 Trace elements (ppm)

\begin{tabular}{|c|c|c|c|c|c|c|c|c|}
\hline & 1 & 2 & 3 & 4 & 5 & 6 & 7 & Av \\
\hline \multicolumn{9}{|c|}{ Core-stone } \\
\hline V & 300 & 280 & 290 & 300 & 310 & 290 & 300 & 295.7 \\
\hline $\mathrm{Cr}$ & 85 & 88 & 90 & 88 & 85 & 90 & 85 & 87.3 \\
\hline Co & 55 & 52 & 53 & 55 & 54 & 55 & 54 & 54.0 \\
\hline $\mathrm{Ni}$ & 44 & 43 & 45 & 46 & 44 & 45 & 45 & 44.6 \\
\hline $\mathrm{Zn}$ & 75 & 80 & 77 & 75 & 80 & 78 & 80 & 77.9 \\
\hline $\mathrm{Rb}$ & 20 & 21 & 21 & 20 & 20 & 21 & 22 & 20.7 \\
\hline $\mathrm{Sr}$ & 360 & 365 & 370 & 350 & 365 & 360 & 385 & 365.0 \\
\hline Y & 35 & 35 & 36 & 35 & 36 & 36 & 35 & 35.4 \\
\hline $\mathrm{Zr}$ & 220 & 219 & 220 & 219 & 220 & 220 & 230 & 221.1 \\
\hline $\mathrm{Ba}$ & 225 & 230 & 230 & 225 & 220 & 230 & 222 & 226.0 \\
\hline La & 22 & 23 & 22 & 23 & 21 & 22 & 22 & 22.1 \\
\hline $\mathrm{Ce}$ & 50 & 51 & 50 & 51 & 52 & 50 & 51 & 50.7 \\
\hline $\mathrm{Pb}$ & 3 & 3 & 3 & 2 & 3 & 3 & 3 & 2.9 \\
\hline Th & 3 & 3 & 3 & 2 & 3 & 2 & 2 & 2.6 \\
\hline \multicolumn{9}{|c|}{ Shell around core-stone } \\
\hline V & 265 & 248 & 257 & 265 & 275 & 257 & 265 & 261.7 \\
\hline $\mathrm{Cr}$ & 79 & 82 & 74 & 82 & 79 & 78 & 85 & 79.9 \\
\hline Co & 55 & 52 & 53 & 55 & 54 & 55 & 54 & 54.0 \\
\hline $\mathrm{Ni}$ & 36 & 35 & 39 & 38 & 36 & 37 & 46 & 38.1 \\
\hline Zn & 58 & 73 & 70 & 68 & 73 & 71 & 81 & 72.0 \\
\hline $\mathrm{Rb}$ & 10 & 11 & 10 & 10 & 10 & 11 & 11 & 104 \\
\hline $\mathrm{Sr}$ & 334 & 296 & 301 & 294 & 286 & 295 & 295 & 300.1 \\
\hline Y & 35 & 35 & 36 & 35 & 36 & 36 & 35 & 35.4 \\
\hline $\mathrm{Zr}$ & 222 & 221 & 222 & 221 & 222 & 222 & 232 & 222.9 \\
\hline $\mathrm{Ba}$ & 251 & 253 & 254 & 251 & 249 & 245 & 250 & 250.4 \\
\hline La & 22 & 23 & 22 & 23 & 21 & 22 & 22 & 22.1 \\
\hline $\mathrm{Ce}$ & 51 & 52 & 51 & 52 & 53 & 51 & 52 & 51.2 \\
\hline $\mathrm{Pb}$ & 3 & 3 & 3 & 2 & 3 & 3 & 3 & 2.9 \\
\hline Th & 3 & 3 & 3 & 2 & 3 & 2 & 2 & 2.6 \\
\hline
\end{tabular}

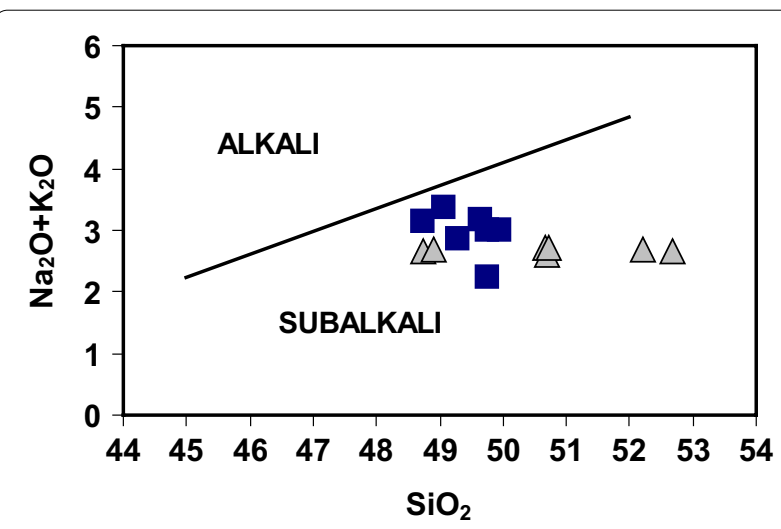

Fig. 3 Total alkali-silica diagram; the solid line is the boundary line of Macdonald and Katsura; the core-stones (black squares) and their shells (triangles) lie below the solid line in the field of subalkali (tholeiitic) basalts shell, indicating higher weathering than in other samples, whereas sample No. 4 shows the least difference, indicating minimum weathering. On average, the WIP decreases from 71 in the core-stone to 58 in the weathered shell.

The CIA, monitors the progressive alteration of feldspars in the samples. The high CIA values reflect the removal of mobile cations $(\mathrm{Ca}, \mathrm{Na}, \mathrm{K})$ relative to $\mathrm{Al}$ during weathering (Nesbitt and Young 1982). Table 1 shows that the CIA values of the core-stones of the basalt spheroids range from 37 to 41 . The weathered shells have higher CIA values than their corresponding core-stones, ranging from 45 to 50 . On average the CIA increases from 39 in the core-stone to 48 in the weathered shell. This slight increase indicates the low degree of weathering characteristic of incipient weathering. In this case, the feldspars in the core-stones were not excessively altered. As a matter of fact, the X-ray 


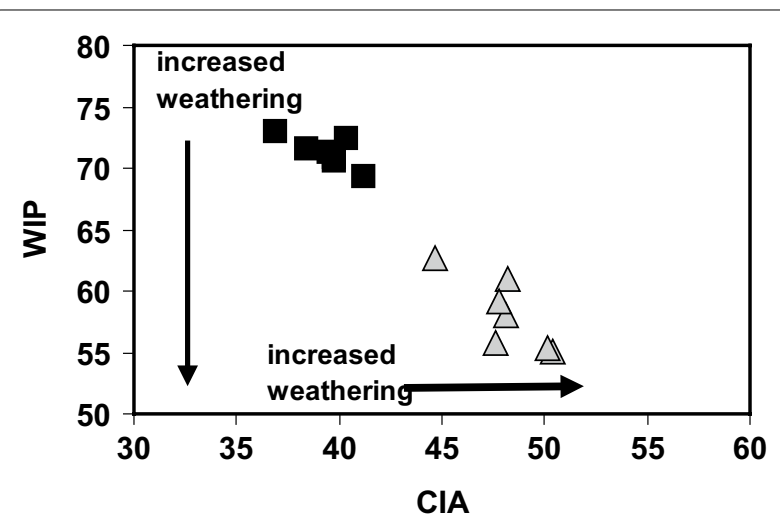

Fig. 4 Relationship between WIP and CIA. The WIP decreases from the core-stones of the basalt spheroids to the corresponding weathered shells, whereas the CIA increases

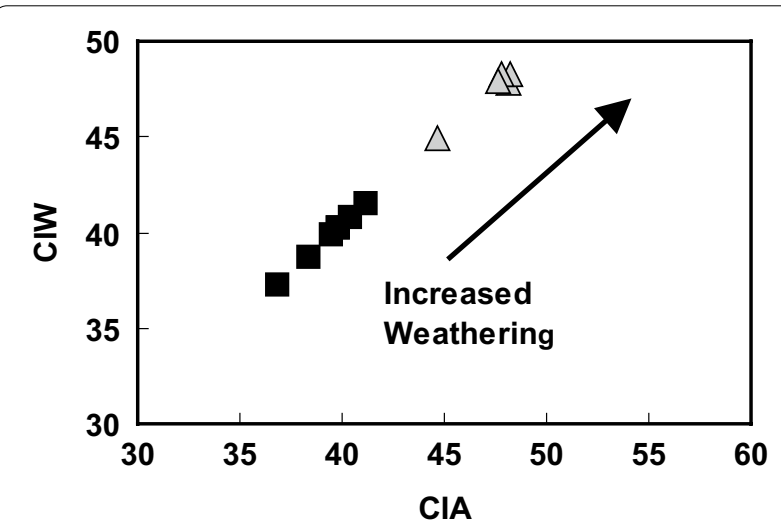

Fig. 5 Relationship between CIW and CIA. A positive correlation exists between the two indices, both increase from the core-stones of the basalt spheroids to the corresponding weathered shells

diffraction analysis of the weathered shells indicated the presence of peaks of feldspars.

Harnois (1988) pointed out that potassium cations leached during weathering can be fixed by adsorption on weathering products, especially clays, and this may disturb the geochemical trend of potassium. He, therefore, proposed the chemical index of weathering (CIW) as an improved index of the degree of weathering to WIP or CIA. The CIW index increases with the degree of depletion in $\mathrm{Na}$ and $\mathrm{Ca}$ relative to Al. Table I shows that CIW increased from the core-stones of the basalt spheroids (average CIW of 40) to the corresponding weathered shells (average CIW of 48).

Figures 4 and 5 show the relationship between WIP and CIA, and between CIW and CIA, respectively. Figure 4 shows the decrease in WIP and increase in CIA from the core-stone samples to the corresponding weathered shells. Figure 5 shows that there is a linear correlation between CIW and CIA, both indices increase from the core-stone samples to the corresponding weathered shells.

Babechuk et al (2014) proposed the mafic index of alteration (MIA) as a chemical weathering index that extends the equation of the CIA to include the mafic elements $\mathrm{Mg}$ and Fe. It is known that many of the mafic minerals (especially pyroxene and olivine) are susceptible to chemical weathering, resulting in the loss of $\mathrm{Mg}$ from the weathering products. The fate of Fe during the weathering of most mafic minerals is, however, redoxdependent. In reducing environments, ferrous iron can be mobile and is leached along with $\mathrm{Mg}$. In oxidative weathering environments, however, Fe is usually retained as insoluble ferric iron oxide or oxyhydroxide and thus enriched along with Al. Two equations have been suggested by Babechuk et al. (2014) for the calculation of MIA, one for oxidizing environment and the second for reducing environment. Table 1 gives the calculated values of $\mathrm{MIA}(\mathrm{O})$, as it is expected that an oxidizing environment had prevailed during the weathering of Gebel Qatrani basalt MIA $(\mathrm{O})$ increases from the core-stones of the basalt spheroids (average MIA of 37) to the corresponding weathered shells (average MIA of 46), indicating that iron from the mafic minerals in the core-stones was conservatively preserved as ferric oxide and/or oxyhydroxide, with progressive weathering.

Because of the complexity of geological systems and the weathering process, Nesbitt and Young (1982) and Nesbitt and Wilson (1992) used the A-CN-K ternary diagram to explain the trend of weathering, rather than depending on single indices like PIW, CIA or CIW. This diagram portrays the molar proportions of $\mathrm{Al}_{2} \mathrm{O}_{3}$ (A apex), $\mathrm{CaO}^{*}+\mathrm{Na}_{2} \mathrm{O}\left(\mathrm{CN}\right.$ apex) and $\mathrm{K}_{2} \mathrm{O}$ (K apex). Figure 6 shows the weathering trend from the core-stones of the basalt spheroids to the corresponding weathered shells. This trend is adjacent and parallel to the CN-A axis, as predicted by Nesbitt and Wilson (1992) for basalts. If weathering had progressed further than that, clay minerals should have been produced at the expense of feldspars and the bulk composition of weathered samples would have moved up the trend in the diagram towards the A apex. Since the weathered shells of the basalt spheroids plot at the lower part of the weathering trend (Fig. 6), this indicates that the weathering had been in the initial (incipient) stage.

The depletion of the various elements from the weathering regime is related to the nature of the host primary minerals, the mobility of these elements once they are released by the weathering of these minerals, and the susceptibility of the elements to retention in new phases in their immediate environment. To evaluate the chemical changes during weathering, it is necessary to assume that 


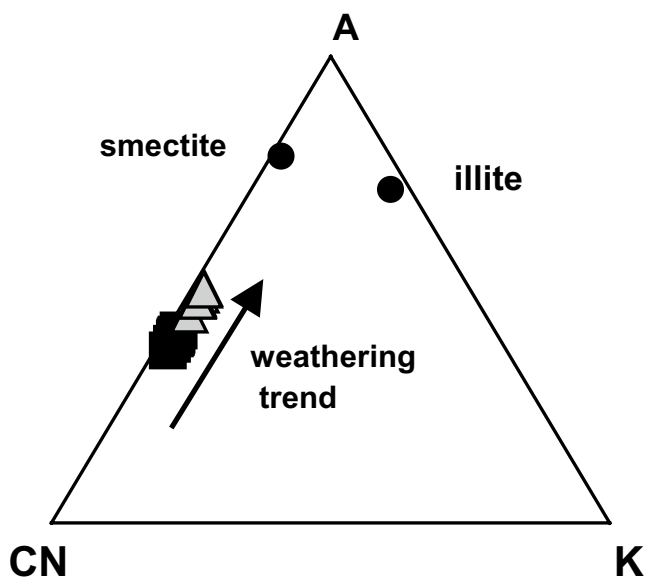

Fig. 6 A-CN-K ternary diagram showing the weathering trend from the core-stones of the basalt spheroids to the weathered shells. The trend is adjacent and parallel to the $\mathrm{CN}-\mathrm{A}$ axis

one chemical component is stable and not removed during the weathering process. For this purpose (e.g., Nesbitt et al. 1980; Nesbitt and Wilson 1992; Kurtz et al. 2000; Patino et al. 2003; Ma et al. 2007), $\mathrm{TiO}_{2}$ was chosen by several authors (see, e.g., Nesbitt and Wilson 1992).

In the present work, we studied the variability of the element concentrations in the shells of the basalt spheroids after normalizing them to $\mathrm{TiO}_{2}$ concentrations and then compared them to the core-stones. The percentage change in the $\mathrm{TiO}_{2}$-normalized concentration of an element in the shell to that in the core-stone was calculated according to the following (Nesbitt 1979; Nesbitt and Wilson 1992):

$$
\% \text { change to ratio }=100 \times\left[\left(R_{\mathrm{sh}}-R_{\mathrm{cs}}\right) / R_{\mathrm{cs}}\right]
$$

here $R_{\mathrm{sh}}$ and $R_{\mathrm{cs}}$ are the elemental ratios in the shell and the core-stone, respectively. The assumption for this type of calculation is that there is no volume change between the weathering product and the un-weathered rock (Nahon and Merino 1996).

Figure 7 shows the average percentage change in the ratios of the major elements in the shell to core-stones of the basalt spheroids. The $\mathrm{Mg} / \mathrm{Ti}, \mathrm{Ca} / \mathrm{Ti}, \mathrm{Na} / \mathrm{Ti}$ and $\mathrm{K} /$ $\mathrm{Ti}$ ratios decrease from the core-stone to the weathered shell. The decrease in $\mathrm{Mg}$ is attributed to the rapid weathering of olivine in the core-stone. $\mathrm{Ca}$ is associated primarily in plagioclase, clinopyroxene and glassy material, all of which weather less rapidly than olivine. Therefore, $\mathrm{Ca} /$ Ti decreases less rapidly than $\mathrm{Mg} / \mathrm{Ti}$ in incipient weathering. $\mathrm{Na}$ and $\mathrm{K}$ reside in plagioclase feldspars which are less readily weathered than olivine and clinopyroxenes. In contrast to $\mathrm{Mg}, \mathrm{Ca}, \mathrm{Na}$ and $\mathrm{K}, \mathrm{Al}$ and $\mathrm{Si}$ are more conservative in incipient weathering and the $\mathrm{Al} / \mathrm{Ti}, \mathrm{Si} / \mathrm{Ti}$ ratios show slight or no increase during weathering. Fe/ Ti ratio shows an increase in early weathering, but rapid decrease during more advances weathering (Nesbitt and Wilson 1992). Mn/Ti ratio decreases with increased weathering, and $\mathrm{P} / \mathrm{Ti}$ ratio increases in early weathering but decreases in advanced weathering.

Figure 8 shows the average percentage change in the ratios of trace elements in the shell to core-stones of the basalt spheroids. $\mathrm{V} / \mathrm{Ti}, \mathrm{Cr} / \mathrm{Ti}, \mathrm{Ni} / \mathrm{Ti}, \mathrm{Zn} / \mathrm{Ti}, \mathrm{Rb} /$ $\mathrm{Ti}$ and $\mathrm{Sr} / \mathrm{Ti}$ ratios show varying rates of decrease during weathering. $\mathrm{V}$ and $\mathrm{Cr}$ reside in clinopyroxenes, glass and oxides, and $\mathrm{V} / \mathrm{Ti}$ and $\mathrm{Cr} / \mathrm{Ti}$ show slight decrease in incipient weathering. $\mathrm{Ni}$ is primarily located in olivine and $\mathrm{Zn}$ in clinopyroxene and glass; both $\mathrm{Ni} / \mathrm{Ti}$ and $\mathrm{Zn} /$

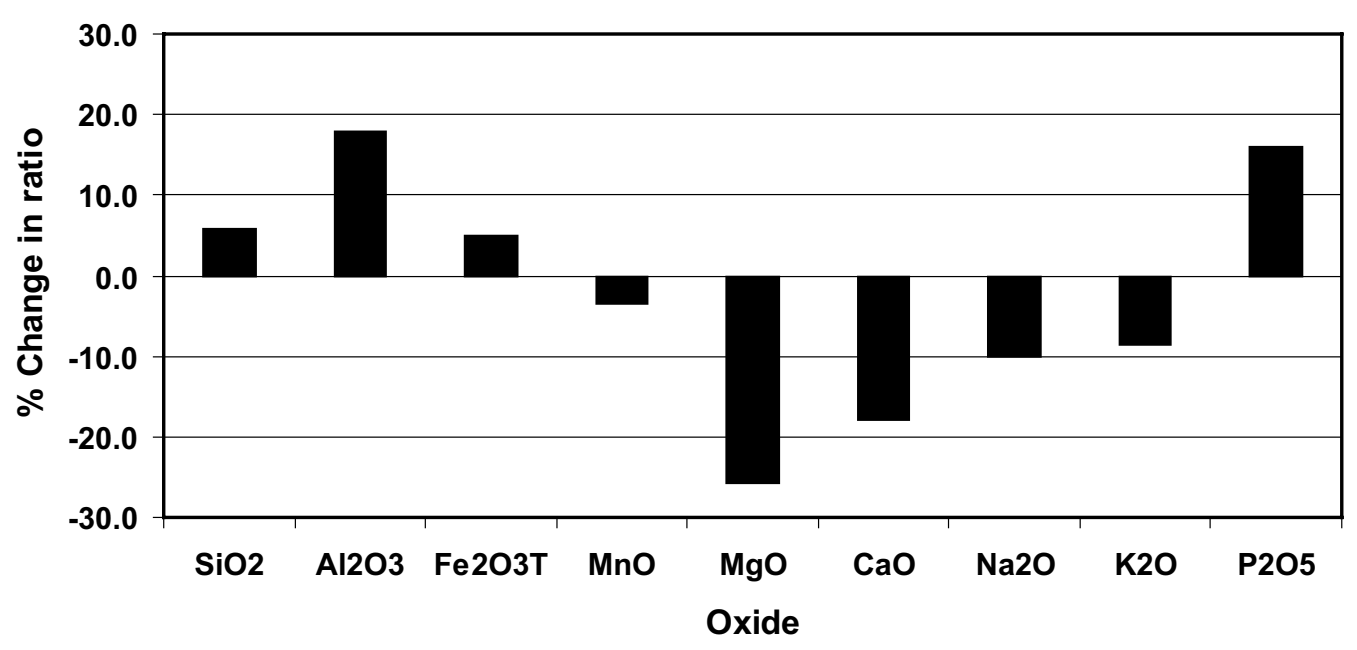

Fig. 7 Percent change in the ratio of major oxides/ $\mathrm{TiO}_{2}$ between average weathered shell and average core-stone 


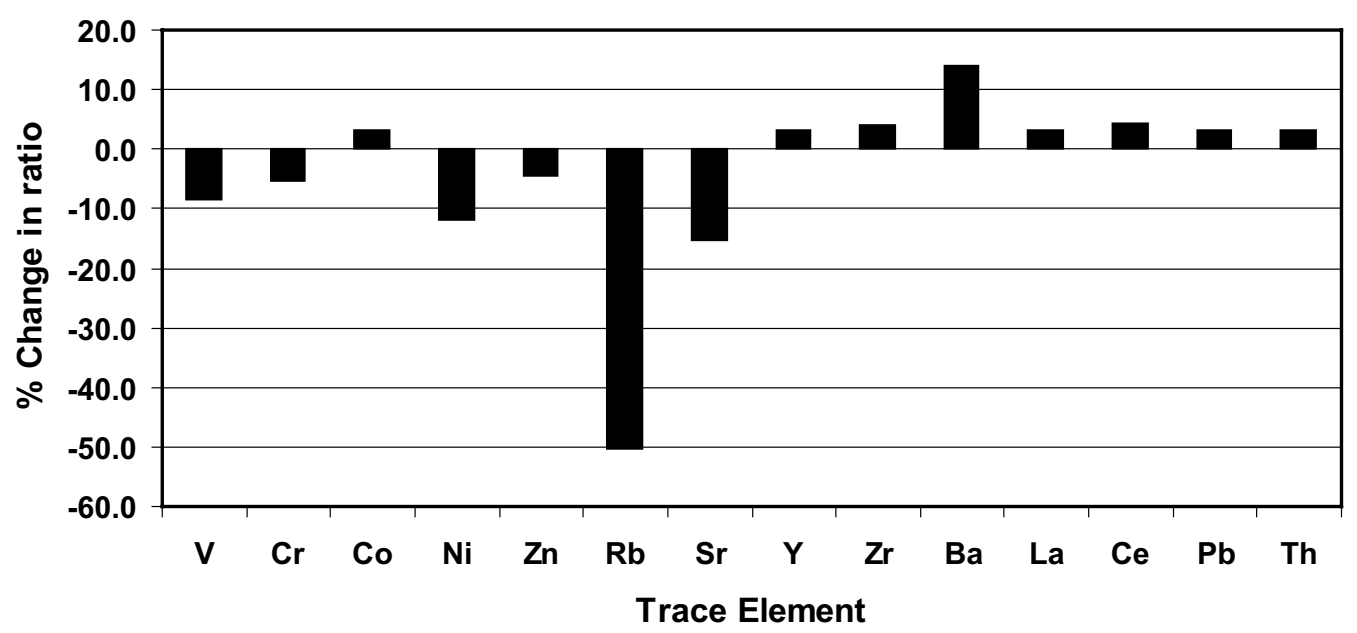

Fig. 8: Percent change in the ratio of trace elements $/ \mathrm{TiO}_{2}$ between average weathered shell and average core-stone

Ti ratios decrease in early weathering. Sr resides primarily in plagioclase, and like $\mathrm{Na}$, the $\mathrm{Sr} / \mathrm{Ti}$ ratio decreases with increased weathering. $\mathrm{Rb}$ resides also in plagioclase and in glass and $\mathrm{Rb} / \mathrm{Ti}$ ratio decreases like $\mathrm{K} / \mathrm{Ti}$ ratio with weathering. On the other hand, the remaining trace elements (Co, Y, Zr, La, Ce, $\mathrm{Pb}$ and $\mathrm{Th}$ ) are more conservative and their ratios show no change or slight increase. $\mathrm{Ba}$ released during weathering may be rapidly precipitated by sorption to secondary minerals, and hence the high $\mathrm{Ba} /$ Ti ratio (Nesbitt and Wilson 1992).

\section{Discussion}

The petrographical, mineralogical and chemical characteristics of the core-stones and the weathered shells of the basalt spheroids indicate that the weathering of Gebel Qatrani basalt is of the incipient stage. The chemical weathering indices, WIP, CIA and CIW, indicate slight weathering and rather low rates of release of mobile elements. Such weathering of the basalt must have taken place under semiarid to arid conditions. This interpretation is, more or less, in agreement with that reached Frey et al. (2013) in their study of the weathering of basalt in the semiarid Deschutes Basin of central Oregon. Novikov et al. (1993) studied the basalt crusts from Syria and pointed out that they reflect significant climate fluctuations in the region, from semiarid (Miocene basalt) to humid warm (Pliocene basalt) and finally to arid conditions (Quaternary basalt).

In Fayum area Bown et al. (1982) and Bown and Kraus (1988) pointed out that in Oligocene times, the Fayum area was subtropical to tropical lowland coastal plain with damp soils and seasonal rainfall that supported an abundance of and variety of vegetation, and large and varied vertebrate fauna. In post-Oligocene times, after the eruption of Gebel Qatrani basalt, the climatic conditions must have changed. El-Saadawi et al (2014) studied the silicified fossil wood found in the Early Miocene Khashab Formation and found that the woods are characterized by having few wide vessels which are indicative of warm humid climate. However, they pointed out that the mode of occurrence of the fossil trunks and the absence of other plant remains such as twigs and roots indicates that fossil woods were not preserved in situ, but transported from where they grew before silicification. Consequently, the anatomical features of the fossil woods cannot be taken as an indication of the climate at the locality of Gebel Khashab. More recently, Zhang et al. (2014) studied the aridification of the Sahara desert in North Africa using different models and found out that North Africa experienced pronounced aridification from the Early Miocene to the Late Miocene. They indicated that in the Late Oligocene and Early Miocene, North Africa was dominated by semiarid steppe climate with restricted areas of arid desert climate. In the Late Miocene, the arid desert climate expanded across much of North Africa with a greater resemblance to today's conditions. Zhang et al. (2014) pointed out that aridification was due to a reduction in North African precipitation.

If subtropical and tropical humid environment had prevailed in Gebel Qatrani area after the eruption of the basalt, this would have led to the formation of weathering soil profiles on the basalt substrate. No such profiles have been encountered on top of the Gebel Qatrani basalt. Therefore, it can be concluded that the incipient weathering of Gebel Qatrani basalt must have taken place under semiarid to arid conditions. 


\section{Conclusions}

The present study on the spheroidal weathering of basalt from Gebel Qatrani, Fayum Depression, Egypt, indicates that weathering was at the initial (incipient) stage. The indices of chemical weathering (WIP, CIA, CIW and $\operatorname{MIA}(\mathrm{o}))$ and element mobility studies indicate that there was a loss of $\mathrm{Mg}, \mathrm{Ca}, \mathrm{Na}$ and $\mathrm{K}$ during the weathering of the core-stones of the basalt spheroids to the corresponding weathered outer shells. Fe mainly resided with $\mathrm{Al}$, indicating that weathering was under oxidizing conditions. There was also a depletion of $\mathrm{V}, \mathrm{Cr}, \mathrm{Ni}, \mathrm{Zn}, \mathrm{Rb}$ and $\mathrm{Sr}$ due to the weathering of the core-stone. On the other hand, Co, Y, Zr, La, Ce, $\mathrm{Pb}$ and Th behaved essentially conservatively. The low degree of weathering of the basalt spheroids indicates that weathering took place mainly in arid to semiarid environment.

\section{Authors' contributions}

EE-H was responsible for field work and assistance in interpretation of results. SDA was responsible for analytical work and Khalil was responsible for petrography and mineralogy. All three authors were responsible for the preparation of the final manuscript submitted for publication. All authors read and approved the final manuscript.

\section{Funding}

Funding was provided from the budget of the National Research Centre.

\section{Availability of data and materials}

Not applicable.

\section{Ethics approval and consent to participate}

All authors have expressed their ethics approval and consent to participate in the present research work.

\section{Consent for publication}

All authors have expressed their consent to publish the present work.

\section{Competing interests}

There are no competing interests in carrying out the present research.

Received: 8 January 2019 Accepted: 19 November 2020

Published online: 06 January 2021

\section{References}

Abdel Meguid A, El-Metwally A, Morsy M (1992) Tectonic evolution of continental basalts of Egypt: geochemical evidences. Egypt Mineral 4:141-158

Abd-Elshafy E, Metwally MH, Abdel Azwwm S, Mohammed MS (2007) Paleoenvironments of Wadi El-Rayan Eocene southwest Fayum, Egypt, by using community faunal analyses. In: Proceedings of second scientific environmental conference, Zagazig, Egypt, pp 125-141

Babechuk MG, Widdowson M, Kamber BS (2014) Quantifying chemical weathering intensity and trace element release from two contrasting basalt profiles, Deccan Traps, India. Chem Geol 363:56-75

Beadnell HJL (1905) The topography and geology of the Fayum Province of Egypt. Survey Department of Egypt, Cairo

Bown TM, Kraus M (1988) Geology and paleoenvironment of the Oligocene Jebel Qatrani Formation and adjacent rocks, Fayium Depression, Egypt. U.S. Geological Survey Professional Paper 1452

Bown BC, Vondra CF (1974) Paeontological interpretation of the Oligocene Gebel Qatrani Formation, Fayum Depression, Egypt. Annals Feol.Surv. Egypt, IV, 115-138.
Bown TM, Kraus MJ, Wing SL, Fleagh JG, Tiffmey BH, Simons EL, Vondra SE (1982) The Fayoum primate forest revisited. J Hum Evol 11:603-632

Cohen KM, Finney SC, Gibard PL, Fan X-J (2013) The ICS international chronostratigraphic chart. Episodes, 36, 199-204. (Chart updated 15 Jan. 2017)

El-Hinnawi E (1965) Petrographical and geochemical studies on Egyptian basalts. Bull Volcanol 28:3-12

El-Hinnawi E, Abdel Maksoud MA (1968) Petrography of Cenozoic volcanic rocks of Egypt. Geol Rundsch 57:879-890

El-Hinnawi E, Abdel Maksud MA (1972) Geochemistry of Egyptian Cenozoic volcanic rocks. Chem Erde 31:93-112

El-Saadawi W, Kamal El-Din M, Wheeler E, Osman R, El-Faramawi M, El-Noamani Z (2014) Early Miocene woods of Egypt. Int Assoc Wood Anat J 35:35-50

Endress CA, Furman T, Abu El-Rusm MA, Hamdan BB (2011) Geochemistry of $24 \mathrm{Ma}$ basalts from NE Egypt: source components and fractionation history. Geol Soc Lond Spec Publ 357:265-283

Fleagle JG, Bown TM, Obradovich JD, Simons EK (1986) Age of the earliest African anthropoids. Science 234:1247-1249

Frey HM, Szranek KJ, Manon MK, Kisane MT (2013) Slow chemical weathering in a semi-arid climate; changes in the mineralogy and geochemistry of subarial basalt flows in Deschutes River Basin, Central Oregon. Chem Geol 347:135-152

Gingerich PD (1992) Marine mammals (Cetacea and Sirenia) from the Eocene of Gebel Mokattam and Fayum, Eygpt: Stratigraphy, age and paleoenvironments. University of Michigan Papers of aleontology, No. 30, 79p

Gingerich P (1993) Oligocene age of the Gebel Qatrani Formation, Fayum, Egypt. J Hum Evol 24:207-218

Harnois L (1988) The CIW Index: a new chemical index of weathering. Sedim Geol 55:319-322

Heikal MA, Hassan MA, El-Sheshtawi Y (1983) The Cenozoic basalt of Gebel Qatrani. Western desert, Egypt, as an example of continental tholeiitic basalt. Ann Geol Surv Egypt 13:193-209

Kurtz AC, Derry LA, Chadwick OA, Alfano MJ (2000) Refractory element mobility in volcanic soils. Geology 28(8):683-686

Ma JL, Wei GL, Xu WG, Lang YG, Sun WD (2007) Mobilization and redistribution of majir and trace elements during extreme weathering of basalt in Hainan Island, South China. Geochim Cosmochim Acta 71:3223-3237

Macdonald GA, Katsura T (1964) Chemical composition of Hawaiian lavas. J Petrol 5:82-133

Meneisy MY (1990) Vulcanicity. In: Said R (ed) The geology of Egypt. A. Balkema, Rotterdam, pp 157-174

Meneisy MY, Abdel Aal AY (1984) Geochronology of Phanerozoic volcanic activity in Egypt. Bull Fac Sci Ain Shams Univ 25:163-175

Morsy A, Attia MS (1983) Effecys of weathering on the miberalogy and chemical composition of some Egyptian basalts. Mineral Pol 14:101-110

Nahon D, Merino E (1996) Pseudomorphic replacement versus dilation in laterites:petrographic evidence, mechanisms and comsequences for modeling. J Geochem Explor 57:217-225

Nesbitt HW (1979) Mobility and fractionation of rare earth elements during weathering of granodiorite. Nature 279:206-210

Nesbitt WH, Wilson RE (1992) Recent chemical weathering of basalts. Am J Sci 292:740-771

Nesbitt WH, Young GM (1982) Early Proterozoic climates and plate motions inferred from major element chemistry of lutites. Nature 299:715-717

Nesbitt HW, Markovics G, Price RC (1980) Chemical processes affecting alkalis and alkaline earths during continental weathering. Geochim Cosmochim Acta 44:1659-1666

Novikov VM, Sharkov EV, Chernyshev IV (1993) Geochronology of weathering crusts on flood basalts in Syria and the evolution of regional paleoclimate during the last $20 \mathrm{Ma}$. Stratigr Geol Correl 1:627-635

Ollier CD (1971) Causes of spheroidal weathering. Earth Sci Rev 7:127-141

Parker A (1970) An index of weathering for silicate rocks. Geol Mag 107:501-504

Patino LC, Welbel MA, Price JR, Wade JA (2003) Trace element mobility during spheroidal weathering of basalts and andesites in Hawaii and Guatemala. Chem Geol 202:343-364

Rittmann A (1954) Remarks on the eruptive mechanism of the Tertiary volcanoes of Egypt. Bull Volcanol 15:109-117

Said R (1962) The geology of Egypt. Elsevier Publ. Co., Amsterdam

Sharara NAF (1984) Petrochemical and geochemical studies on some midTertiary basalts from Egypt. Egypt J Geol 28:83-112 
Vondra CF (1974) Upper Eocene transitional and near-shore marine Qasr El-Sagha Formation, Fayum Depression, Egypt. Ann Geol Surv Egypt IV:79-94

Zhang Z, Ramstein G, Schuster M, Li C, Contoux C, Yan Q (2014) Aridification of the Sahara desert caused by Tethys Sea shrinkage during the Late Miocene. Nature 513:401-404

\section{Publisher's Note}

Springer Nature remains neutral with regard to jurisdictional claims in published maps and institutional affiliations.
Submit your manuscript to a SpringerOpen ${ }^{\odot}$ journal and benefit from:

- Convenient online submission

- Rigorous peer review

- Open access: articles freely available online

- High visibility within the field

- Retaining the copyright to your article

Submit your next manuscript at $\boldsymbol{\nabla}$ springeropen.com 